\title{
ANALISIS SENTIMEN PADA DATA SARAN MAHASISWA TERHADAP KINERJA DEPARTEMEN DI PERGURUAN TINGGI MENGGUNAKAN CONVOLUTIONAL NEURAL NETWORK
}

\author{
Yuliska $^{* 1}$, Dini Hidayatul Qudsi ${ }^{2}$,Juanda Hakim Lubis ${ }^{3}$, Khairul Umam Syaliman ${ }^{4}$, Nina Fadilah Najwa \\ 1,24,5 Politeknik Caltex Riau, ${ }^{3}$ Universitas Medan Area Medan \\ Email: ${ }^{1}$ yuliska@pcr.ac.id, ${ }^{2}$ dinihq@pcr.ac.id, ${ }^{3}$ juandahakim@gmail.com, ${ }^{4}$ khairul@pcr.ac.id, ${ }^{5}$ nina@pcr.ac.id
}

*Penulis Korepondensi

(Naskah masuk: 15 Maret 2021, diterima untuk diterbitkan: 19 Oktober 2021)

\begin{abstract}
Abstrak
Review atau saran dari customer dapat menjadi sangat penting bagi penyedia layanan, begitu pula saran dari mahasiswa mengenai layanan sebuah unit kerja di perguruan tinggi. Review menjadi penting karena dapat menjadi indikator kinerja penyedia layanan. Pengolahan review juga sangat penting karena dapat menjadi referensi untuk pengambilan keputusan dan peningkatan layanan yang lebih baik ke depannya. Penelitian ini menerapkan analisis sentimen pada data saran atau review mahasiswa terhadap kinerja unit kerja atau departemen di perguruan tinggi, yaitu Politeknik Caltex Riau. Analisis sentimen dilakukan dengan menggunakan Convolutional Neural Network (CNN) dan word embedding Word2vec sebagai representasi kata. CNN merupakan metode yang memiliki performa yang baik dalam mengklasifikasi teks, yaitu dengan teknik convolutional yang menggabungkan beberapa window kata pada kalimat dan mengambil window yang paling representative. Word $2 \mathrm{Vec}$ digunakan sebagai representasi data saran dan inputan awal pada CNN, dimana Word2Vec merupakan dense vectors yang dapat merepresentasikan hubungan antar kata pada data saran dengan baik. Saran mahasiswa dapat mengandung kalimat yang sangat panjang, karena itu perpaduan Word2Vec sebagai representasi kata dan $C N N$ dengan teknik convolutional, dapat menghasilkan representasi yang representative dari kalimat panjang tersebut. Penelitian ini menggunakan dua arsitektur CNN, yaitu Simple CNN dan DoubleMax CNN untuk mengidentifikasi pengaruh kompleksitas arsitektur terhadap hasil klasifikasi sentimen. Berdasarkan hasil pengujian, DoubleMax CNN dapat mengklasifikasi sentimen pada saran mahasiswa dengan sangat baik, yaitu mencapai Akurasi tertinggi sebesar 98\%, Recall 97\%, Precision 98\% dan F1-Score 98\%.
\end{abstract}

Kata kunci: Analisis Sentimen, Convolutional Neural Network, Kinerja Department, Saran Mahasiswa

\section{SENTIMENT ANALYSIS IN THE STUDENT'S REVIEWS OF COLLEGE DEPARTMENT PERFORMANCE USING CONVOLUTIONAL NEURAL NETWORK}

\begin{abstract}
Student's reviews about department performance can be essential for a college for it can be used to evaluate the department performance and to take an immediate action to improve its performance. This research applies sentiment analysis in the student's reviews of college department in Politeknik Caltex Riau. Convolutional Neural Network and Word2Vec are employed to analyze the sentiment. CNN is known for its good performance in text classification by applying a convolutional technique to the input sentences. Word2Vec is used as word representation and as an input to the CNN. Word2Vec are dense vectors which can represent the relationship between words excellently. Student's reviews can be a long sentence; hence the combination of Word2Vec as word representation and CNN with convolutional technique can produce a representative fiture from that long sentence. This research utilizes two CNN architectures, which are Simple CNN dan DoubleMax CNN to identify the effect of the complexity of $C N N$ architecture to final result. Our experiments show that DoubleMax CNN has a great performance in classifying sentiment in the student's reviews with the best Accuracy value of 98\%, Recall 97\%, Precision 98\% and F1-Score value of 98\%.
\end{abstract}

Keywords: Convolutional Neural Network, Department Performance, Sentiment Analysis, Student's Reviews

\section{PENDAHULUAN}

Semakin berkembangnya teknologi, semakin banyak pula pengguna yang menggunakan internet sebagai sumber informasi. Peranan internet sebagai sumber informasi membuat banyak pengguna menggunakan internet untuk berbagi pendapat pribadinya yang dituangkan dalam bentuk saran atau 
review. Saran atau review ini dapat berupa pendapat pribadi pengguna mengenai kualitas sebuah film, kualitas produk, pelayanan toko online, pelayanan sebuah lembaga, pelayanan hotel, dan lain sebagainya (Pang \& Lee, 2008). Banyak situs atau website yang menyediakan fitur kuesioner agar pengguna dapat menyampaikan pendapat mereka mengenai hotel, restoran, atau tempat-tempat wisata (Tsytsarau \& Palpanas, 2012). Hasil review kemudian akan digunakan untuk pengambilan keputusan yang lebih baik (Raut \& Londhe, 2014). Fitur kuesioner atau review ini juga diterapkan pada perguruan tinggi, salah satunya untuk memberikan review terhadap kinerja dosen (Salam, Supianto \& Perdanakusuma, 2019). Namun, kinerja dosen bukan satu-satunya indikator untuk mengukur kualitas sebuah perguruan tinggi. Pelayanan yang baik dari unit-unit atau departemen pada sebuah perguruan tinggi juga menjadi salah satu indikator penting, karena itu pengolahan data saran secara efisien sangat diperlukan. Salah satu teknik yang dapat diterapkan agar pengolahan data saran menjadi lebih efisien yaitu teknik analisis sentimen. Analisis sentimen adalah suatu proses klasifikasi menjadi dua polarity atau kecenderungan (binary classification), yaitu positif dan negatif (Gupta, Tiwari \& Robert, 2016). Dengan penerapan analisis sentimen terhadap data saran, akan diketahui kecenderungan saran mahasiswa atau kepuasan mahasiswa terhadap kinerja sebuah unit kerja, apakah positif atau negatif. Sehingga pengambilan keputusan dan peningkatan layanan untuk kinerja yang lebih baik ke depannya dapat segera diterapkan.

Hamzah (2014) mengukur tingkat kepuasan mahasiswa dalam proses pembelajaran di AKPRIND dengan memanfaatkan analisis sentimen. Penelitian ini menggunakan metode Nä̈ve Bayes dalam mengklasifikasi sentimen, dengan representasi kalimat menggunakan teknik TF-IDF. Dengan menggunakan Nä̈ve Bayes dan TF-IDF sebagai representasi kata, penelitian ini berhasil mendapatkan rata-rata akurasi $85.95 \%$.

Salam, Supianto \& Perdanakusuma (2019) juga melakukan analisis sentimen pada opini mahasiswa terhadap kinerja dosen di Fakultas Ilmu Komputer Universitas Brawijaya (FILKOM UB). Penelitian ini dilakukan dengan tujuan agar data saran mahasiswa dapat diolah secara mendalam dan dijadikan bahan evaluasi untuk peningkatan kinerja dosen. Kombinasi $T F-I D F$ dan K-Nearest Neighbor (KNN) digunakan dalam mengklasifikasi sentimen pada opini mahasiswa yang menghasilkan rata-rata akurasi sebesar $81 \%$.

Penelitian selanjutnya menggunakan Support Vector Machine (SVM) untuk menganalisis sentimen data kritik dan saran dari sebuah pelatihan bertema teknologi informasi (APLINET) (Al Kabir, Basuki \& Wicaksono, 2019). Analisis sentimen dilakukan untuk mengevaluasi tanggapan peserta dari pelatihan yang telah dilakukan. Proses analisis sentimen diawali dengan melakukan beberapa langkah text preprocessing, kemudian dilakukan pembobotan $T F$ -
$I D F$. Proses akhir dari penelitian ini yaitu klasifikasi sentimen data saran mengunakan Support Vector Machine yang mendapatkan akurasi sebesar $82.08 \%$.

Kemudian, analisis sentimen terhadap teks berbahasa Indonesia dengan menggunakan salah satu metode deep learning yaitu Convolutional Neural Network (CNN) telah dilakukan oleh (Juwiantho et al., 2020), yaitu terhadap 999 data Twitter berbahasa Indonesia. Berbeda dengan penelitian-penelitian sebelumnya, penelitian ini menggunakan Word2Vec dengan berbagai dimensi (50 s/d 300) sebagai representasi kata dengan arsitektur CNN yang digunakan adalah $C N N$ dengan sebuah convolutional layer yang diikuti dengan sebuah operasi Max-Pooling. Hasil percobaan dari penelitian ini adalah akurasi terbaik sebesar $76.40 \%$ dengan pilihan dimensi Word2Vec terbaik yaitu 100. Walau akurasi yang didapat sudah cukup baik, akurasi masih dapat ditingkatkan dengan penggunaan arsitektur $C N N$ yang lebih kompleks, seperti penambahan layer konvolusi dan pemilihan filter yang tepat.

Penggunaan $C N N$ dengan berbagai arsitektur untuk menganalisis sentimen dilakukan oleh (Kim \& Jeong, 2019), namun untuk korpus dengan teks berbahasa inggris, yaitu user review terhadap kualitas film dan produk. Penelitian ini menggunakan arsitektur CNN mulai dari yang sangat sederhana yang hanya terdiri dari sebuah layer konvolusi, hingga arsitektur yang terdiri dari 3 buah layer konvolusi. Hasil dari penelitian ini menunjukkan bahwa $C N N$ yang memiliki lebih dari sebuah layer konvolusi bekerja lebih baik dibandingkan dengan $C N N$ dengan sebuah layer konvolusi. Namun, CNN dengan banyak convolutional layer tidak selalu memiliki performa yang tinggi. Kompleksitas atau kedalaman network harus ditentukan berdasarkan karakteristik data, karena network yang terlalu kompleks terkadang dapat mengakibatkan overfitting.

Pada penelitian ini, data yang digunakan adalah data review atau kuisioner mahasiswa terhadap kinerja 7 departemen kerja di Politeknik Caltex Riau (PCR). Politeknik Caltex Riau adalah sebuah perguruan tinggi swasta di provinsi Riau yang berdiri pada tahun 2001. Data saran mahasiswa terhadap kinerja suatu unit dapat mencapai 1500 saran per departemen, dengan jumlah kata dapat mencapai 150 kata per data saran. Kontribusi dari penelitian ini adalah penerapan metode Convolutional Neural Network (CNN) untuk mengklasifikasi sentimen data saran mahasiswa terhadap kinerja atau pelayanan sebuah unit kerja. Metode CNN yang diusulkan memiliki 2 buah arsitektur. Arsitektur pertama terdiri dari 2 layer dengan operasi Max-Pooling di masing-masing layer (DoubleMax CNN). Arsitektur kedua terdiri dari 2 convolutional layer dengan operasi Max-Pooling di layer terakhir (Simple CNN). Dua buah arsitektur CNN ini digunakan untuk mengidentifikasi pengaruh kompleksitas arsitektur $C N N$ terhadap hasil klasifikasi sentimen terhadap data saran, terutama klasifikasi sentimen terhadap kalimat yang panjang karena saran mahasiswa terhadap sebuah unit dapat berupa kalimat 
yang sangat panjang (150 kata). Oleh sebab itu, penelitian ini tidak menggunakan $T F-I D F$ sebagai representasi kata, karena $T F-I D F$ tidak dapat merepresentasikan keterkaitan antar kata dengan baik. Penelitian ini menggunakan Word2Vec berbahasa Indonesia sebagai representasi kata. Word2Vec terbukti dapat menjadi representasi yang lebih baik dibanding $T F-I D F$ untuk teks berbahasa Indonesia (Juwiantho et al., 2020). Word2Vec akan menjadi inputan awal CNN, kemudian $C N N$ akan menentukan pola data saran yang dilabeli positif, negatif dan netral. Hasil penelitian ini diharapkan dapat menghasilkan teknik atau metode yang dapat mengklasifikasi sentimen dengan 2 dan 3 kecenderungan yang memiliki performa tinggi.

\section{METODE PENELITIAN}

Tahapan-tahapan yang akan dilakukan pada penelitian ini dapat dilihat pada Gambar 1. Penelitian diawali dengan melakukan analisis terhadap masalah yang terjadi terkait pengolahan data saran mahasiswa terhadap kinerja unit kerja atau departemen di PCR. Dari tahapan analisis masalah ini, teridentifikasi bahwa pengolahan data saran mahasiswa terhadap kinerja unit kerja PCR masih belum menerapkan analisis sentimen. Sehingga data saran belum terfilter menjadi saran positif dan negatif yang dapat digunakan untuk pengambilan keputusan dan perbaikan kualitas pelayanan. Kemudian dilanjutkan dengan pengumpulan data saran dimana data saran yang dikumpulkan adalah dalam bentuk file.csv yang didapatkan dari Badan Perencanaan, Pengembangan dan Penjaminan Mutu (BP3M) PCR. Proses selanjutnya yaitu proses preprocessing terhadap data yang telah terkumpul.

Setelah itu, karena metode yang akan digunakan untuk melakukan analisis sentimen atau sentiment analysis adalah metode supervised, maka perlu dilakukan proses labelling terhadap data saran agar proses training dapat dilakukan. Labelling yang dilakukan pada penelitian ini adalah automatic labelling, yaitu memberikan label sentimen positif, negatif dan netral kepada setiap data saran, yang dilakukan secara otomatis dengan menggunakan beberapa rules. Setelah tahapan labelling, proses selanjutnya yaitu melakukan training word2vec model untuk mendapatkan word embedding atau representasi kata yang nantinya akan digunakan dalam mengklasifikasi sentimen. Training word2vec model pada penelitian ini dilakukan dengan menggunakan artikel wikipedia berbahasa indonesia, yang terdiri dari 415.521 kalimat dan 443.979 kata unik. Proses fine tuning juga dilakukan terhadap word embedding yang sudah didapat, agar word embedding menjadi lebih sesuai dengan kata-kata yang digunakan pada penelitian ini. Kemudian, proses klasifikasi sentimen dengan menggunakan CNN dilakukan. Proses terakhir dari penelitian ini adalah melakukan pengujian terhadap analisis sentimen yang dilakukan dengan menggunakan $C N N$ dan menganalisa hasil pengujian. Hasil pengujian dengan $C N N$ juga akan dibandingkan dengan beberapa metode machine learning (Support Vector Machine, logistic regression dan Naive Bayes) untuk memastikan efektifitas performa $C N N$.

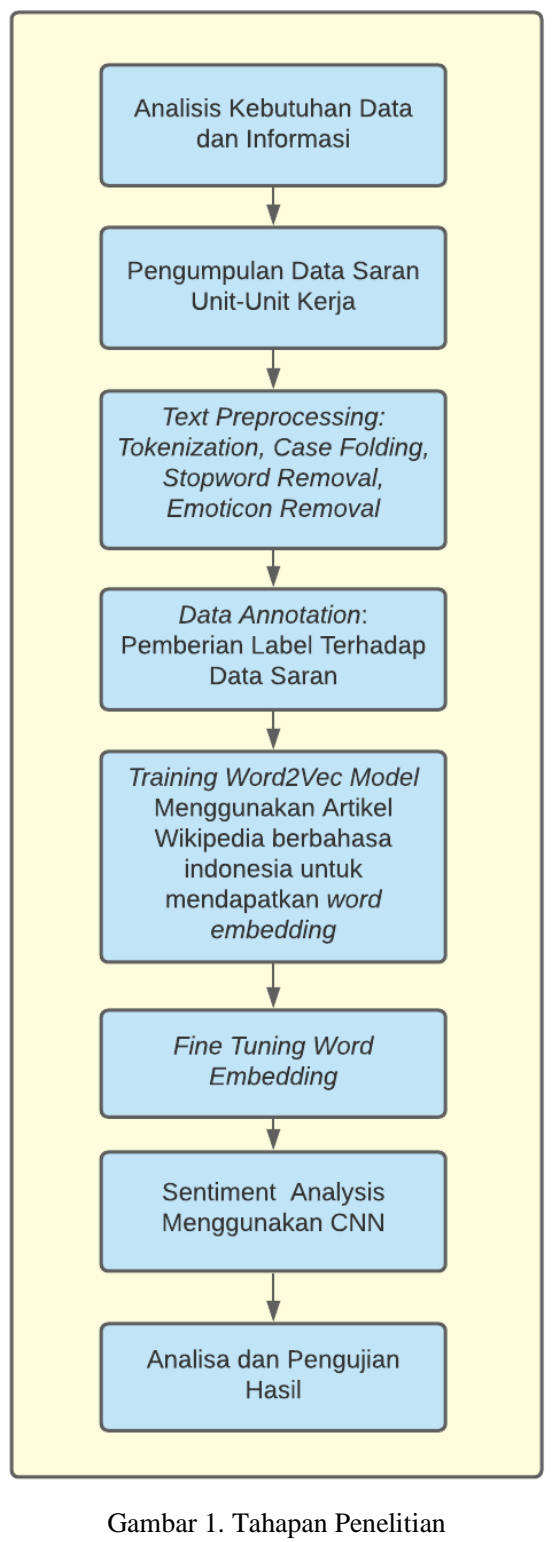

\subsection{Analisis Sentimen}

Analisis sentimen atau Sentiment analysis adalah sebuah bidang yang sangat umum dalam text classification atau klasifikasi teks. Analisis sentimen adalah sebuah proses yang menganalisa dan mendeteksi sentimen sebuah inputan teks memiliki sentimen positif, negatif atau netral (Gupta, Tiwari \& Robert, 2016). Namun, hingga sekarang, sentimen yang dapat dideteksi menjadi lebih beragam dan mendetil dan tidak terbatas hanya kepada positif dan negatif, yaitu dapat mendeteksi happiness (bahagia), sadness (sedih), anger (marah), fear (takut), disgust (jijik) dan surprise (terkejut) (Seyeditabari, Tabari \& Zadrozny, 2018).

Analisis sentimen dapat digunakan salah satunya untuk melakukan monitoring terhadap kualitas atau performa sebuah produk dan pelayanan sebuah lembaga. Dengan menerapkan analisis sentimen pengembang produk dan pemilik layanan dapat dengan 
mudah mengetahui apakah sebuah produk dan layanan diterima secara positif oleh pelanggan atau malah sebaliknya. Kegunaan analis sentimen selanjutnya yaitu untuk menganalisa sebab dibalik diterima atau tidak diterimanya sebuah produk atau layanan (Liu, 2010). Oleh karena itu, analisis sentimen dapat digunakan oleh hampir di semua bidang.

Penelitian di bidang analisis sentimen untuk teks berbahasa Indonesia telah banyak dilakukan, seperti yang sudah dijelaskan di pendahuluan. Data yang digunakan mulai dari review mahasiswa terhadap kinerja dosen, review produk (Attabi, Muflikhah \& Fauzi, 2018), hingga analisis sentimen terhadap data Twitter. Metode yang digunakanpun beragam, mulai seperti SVM, Nä̈ve Bayes, KNN, hingga metode berbasis Deep Learning, seperti CNN.

\subsection{Convolutional Neural Network (CNN)}

Convolutional neural network pada awalnya digunakan pada bidang image processing atau computer vision. Kemudian pada tahun 2015, CNN digunakan pada bidang natural language processing (NLP), yaitu untuk melakukan klasifikasi teks (Kim, 2014). Inti dari CNN dalam mengklasifikasi teks yaitu dengan menerapkan teknik convolution terhadap kalimat, paragraf, atau keseluruhan dokumen teks. Convolution pada dasarnya adalah sliding window yang disebut juga dengan filter, yaitu membagi representasi teks yang berupa matriks menjadi beberapa window, kemudian menjumlahkannya. Hasil penjumlahan inilah yang menjadi representasi baru dari teks yang disebut dengan feature maps. Pada CNN, dikenal pula teknik maxpooling, yaitu pemilihan nomor terbesar dari setiap feature map.

Berikut adalah keterangan poin-poin arsitektur CNN pada Gambar 2:

1) Representasi Kalimat: Setiap kata pada kalimat input merupakan sebuah vector yang berdimensi $k$. Jadi, sebuah kalimat merupakan concatenation atau operasi gabungan dari $n$ representasi kata, yang menghasilkan sebuah matriks $\mathbf{S} \in \mathbb{R}^{k x n}$, matriks ini yang digunakan sebagai input ke convolutional layer. Layer pertama merupakan embedding layer yang mengandung sebuah lookup table di mana word embedding direpresentasikan sebagai matriks $\mathbf{X} \in \mathbb{R}^{k \times|V|}, V$ adalah vocabulary atau kamus kata. Jadi, kolom ke-i pada $\mathbf{X}$ merepresentasikan kata ke$i$ pada kamus kata $V$.

2) Convolutional Layer: Pada layer ini, operasi Convolution dilakukan dengan melibatkan sebuah filter $\mathbf{w} \in \mathbb{R}^{h k}$, yang diterapkan pada sebuah window dari $h$ kata untuk menghasilkan sebuah fitur baru. Sebagai contoh, sebuah fitur $c_{i}$ dihasilkan dari sebuah window kata $\mathbf{s}_{i: i+h-1}$ dengan menggunakan persamaan sebagai berikut:

$c_{i}=f\left(\boldsymbol{w} \cdot \boldsymbol{s}_{i: i+h-1}+b\right)$

Dari persamaan (1) di atas, $b \in \mathbb{R}^{m}$ adalah sebuah bias, $f$ adalah sebuah fungsi non-linier. Filter ini digunakan pada setiap window kata yang terdapat pada kalimat $\left\{\mathbf{s}_{1: h}, \quad \mathbf{s}_{2: h+1}, \ldots, \quad \mathbf{s}_{n-h+1: n}\right\}$ untuk menghasilkan sebuah feature map sebagai berikut:

$\boldsymbol{c}=\left[c_{1}, c_{2}, \ldots, c_{n-h+1}\right]$

Di mana $c \in \mathbb{R}^{n-h+1}$.

3) Max-Pooling: Operasi Max-Pooling adalah mengambil nilai maksimum dari sebuah feature map.

$\hat{c}=\max \{\mathbf{c}\}$

4) Fully Connected Layer: Sebuah Fully Connected Layer menghitung transformasi $\alpha(\mathbf{W} * \mathbf{x}+b)$, dimana $\mathbf{W} \in \mathbb{R}^{m x m}$ adalah weight matrix, $\alpha$ adalah sebuah activation function dan $\mathbf{x} \in \mathbb{R}^{m}$ adalah representasi baru dari kalimat (sentence embedding), yang merupakan output dari layer ini.

5) Dropout: Adalah sebuah teknik alternatif untuk mengurangi terjadinya overfitting, yaitu keadaan di mana dapat diklasifikasi dengan baik pada saat training, namun bekerja sebaliknya pada saat evaluation dan testing. Pada setiap fase training, setiap node atau unit network dimatikan sebanyak probabilitas $p$.

6) Optimization: Adalah sebuah teknik yang digunakan untuk mengubah atribut dari neural network, seperti weight dan learning rate untuk mengurangi loss dari model neural network selama training. Ada banyak optimizer yang dapat digunakan, yaitu Adadelta (Zeiler, 2014), Adam (Kingma \& Ba, 2015), Nadam (Dozat, 2016) dan $S G D$ (Ruder, 2016). Penelitian ini menggunakan Adam sebagai optimizer.

7) Sigmoid: Output dari Fully Connected Layer $\mathbf{x} \in$ $\mathbb{R}^{m}$ terhubung ke sebuah sigmoid layer, yang memberikan output berupa 2 buah class, dimana $\hat{y}$ $\in[0,1]$. 


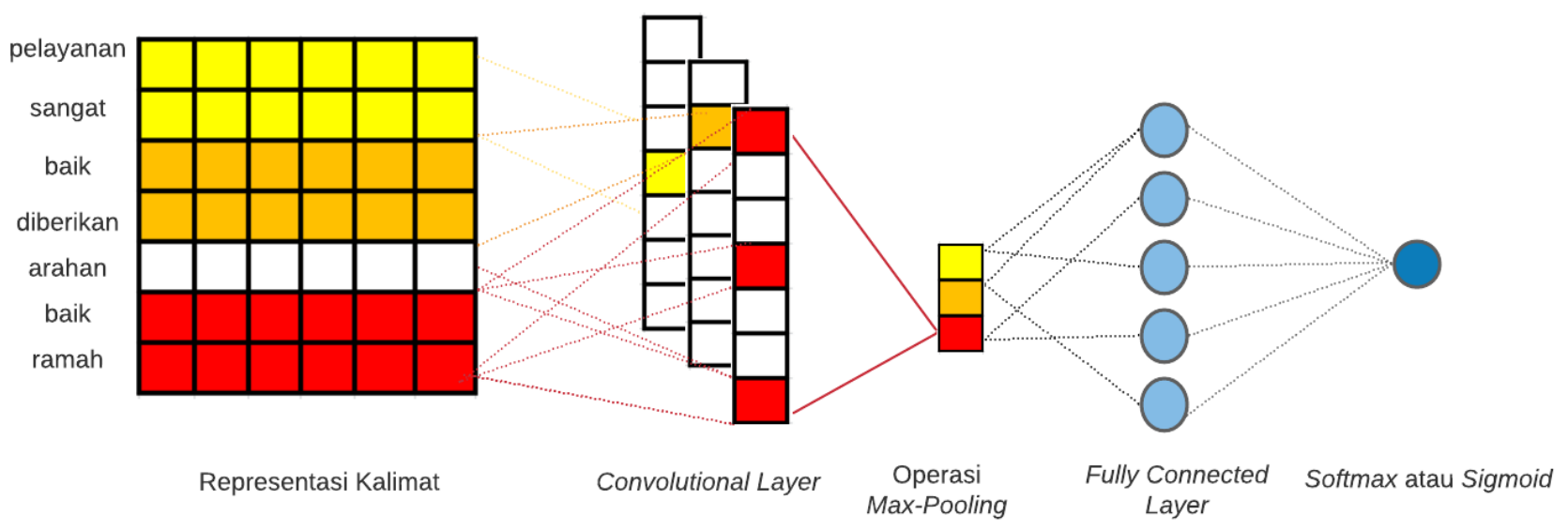

Gambar 2. Arsitektur Convolutional Neural Network (CNN)

$\hat{y}:=\frac{1}{1+e^{-\left(x^{T} \boldsymbol{W}+b\right)}}$

Output akan bernilai 1 jika $\hat{y}$ bernilai lebih besar dari threshold (pada penelitian ini, threshold $=0.5$ ), dan akan bernilai 0 jika sebaliknya.

8) Softmax: Pada multiclass classification, Output dari Fully Connected Layer $\mathbf{x} \in \mathbb{R}^{m}$ terhubung ke sebuah softmax layer, yang memberikan output berupa $K$ buah class, dimana $\hat{y} \in[0, K]$ dengan probabilitas terbesar.

$\hat{y}:=\operatorname{argmax}_{j} \frac{e^{\left(x^{T} \boldsymbol{w}_{j}+b_{j}\right)}}{\sum_{k=1}^{K} e^{\left(\boldsymbol{x}^{T} \boldsymbol{W}_{\boldsymbol{k}}+b_{k}\right)}}$

\subsection{Word2Vec}

Word2Vec (Mikolov et al., 2013) adalah salah satu cara merepresentasikan teks dalam bentuk dense vector yang disebut juga dengan word embedding. Word2Vec dapat memiliki 50 sampai dengan 300 dimensi. Word2Vec mulai ramai digunakan dalam bidang natural language processing di tahun 2013, karena Word2Vec merupakan dense vectors yang dapat merepresentasikan hubungan antar kata dengan lebih baik (dibandingkan dengan $T F-I D F$ ), secara semantik maupun sintaksis. Google telah menyediakan pretrained Word2Vec yang dapat langsung digunakan tanpa perlu melatih atau training model Word2Vec untuk mendapatkan word embedding. Namun, pretrained Word2Vec berbahasa Indonesia belum tersedia, sehingga pada penelitian ini dilakukan training model Word2Vec untuk mendapatkan word embedding berbahasa Indonesia.

\subsection{Parameter Pengujian (Evaluation Metrics)}

Parameter pengujian yang digunakan pada penelitian ini yaitu beberapa metrik confusion matrix, yaitu akurasi, recall, precision, dan $f$-measure.

1) Recall: Menunjukkan jumlah data saran dengan label positif yang terklasifikasi secara benar diantara data yang diprediksi sebagai positif.

Recall $=\frac{T P}{T P+F N}$
2) Precision: Menunjukkan jumlah data saran dengan label positif yang terklasifikasi secara benar diantara semua data dengan label positif. Precision $=\frac{T P}{T P+F P}$

3) Akurasi: Menunjukkan jumlah data saran yang terklasifikasi secara benar (baik yang berlabel positif maupun negatif).

Akurasi $=\frac{T P+T N}{T P+T N+F P+F N}$

4) F1-Score: Menunjukkan harmonic mean dari precision dan recall.

$$
\text { F1 Score }=\frac{2 T P}{2 T P+F P+F N}
$$

Keterangan:

- $\quad$ True Positif (TP): Review dengan label positif yang terklasifikasi sebagai review positif

- True Negatif (TN): Review dengan label negatif yang terklasifikasi sebagai review negatif

- False Positif (FP): Review dengan label positif yang terklasifikasi sebagai review negatif

- False Negatif (FN): Review dengan label negatif yang terklasifikasi sebagai review positif

\section{HASIL DAN PEMBAHASAN}

Pada bagian ini akan dibahas data yang digunakan pada penelitian ini, preprocessing yang dilakukan terhadap data yang digunakan, automatic labeling, training Word2Vec model untuk mendapatkan word embedding, training model CNN, testing model dan menganalisa hasil.

\subsection{Data yang Digunakan}

Data yang digunakan pada penelitian ini adalah data hasil Quality Assurance (QA) penilaian performa layanan unit kerja atau departemen di Politeknik Caltex Riau di semester genap Tahun Ajaran 2018/2019 yang didapatkan dari BP3M PCR. Data QA setiap unit terdiri dari nilai angka dengan range 1-4 untuk beberapa poin pelayanan di masing-masing unit dan data saran atau review dari mahasiswa mengenai pelayanan di masing-masing unit. Yang digunakan pada penelitian ini yaitu data saran atau review dari 
mahasiswa. Jumlah data saran di masing-masing unit adalah mulai dari 1470 hingga 1500 , namun hanya 1200 data saran saja yang akan digunakan, sedangkan 300 data saran lainnya dieliminasi berdasarkan banyak kata yang terkandung di dalamnya dan juga demi keseimbangan data saran di masing-masing kelas (kelas data saran dengan label positif, negatif dan netral). Jumlah kata pada data saran mulai dari 2 kata hingga 150 kata. Tabel 1 berikut menunjukkan contoh data saran di salah satu unit.

Tabel 1. Contoh Data Saran di Salah Satu Unit

\begin{tabular}{cl}
\hline Nomor & \multicolumn{1}{c}{ Saran } \\
\hline 1 & $\begin{array}{l}\text { Pelayanan Sangat baik dan diberikan arahan dengan } \\
\text { baik dan ramah (-) })\end{array}$ \\
2 & $\begin{array}{l}\text { Terapkan pembayaran ansuran agar mahasiswa yang } \\
\text { tidak mampu dapat kemudahan }\end{array}$ \\
3 & $\begin{array}{l}\text { Jangan sampai antrian panjang menanti } \\
\text { Pelayanan yang d berikan sudah baik, penjaga nya }\end{array}$ \\
4 & $\begin{array}{l}\text { juga ramah, dalam menindaklanjuti pembludakan } \\
\text { pembayaran serentak yang dilakukan mahasiswa } \\
\text { harus d perbaiki. }\end{array}$ \\
5 & $\begin{array}{l}\text { Saran dari saya supaya tempat pembayaran SPP di } \\
\text { tambah karna menurut saya kalau 1 bank masi kurang } \\
\text { cukup, sebab admin bank akan kerepotan mengurus } \\
\text { mahasiswa yang mengurus SPP tersebut } \\
\text { Bagian keuangan sudah memberikan pelayanan dan } \\
\text { tanggapan yang memuaskan } \\
\text { Sebaiknya untuk antrian di kasi nomor, agar tidak ada } \\
\text { yang memotong saat ada urusan keuangan }\end{array}$ \\
\hline
\end{tabular}

\subsection{Text Preprocessing}

Penelitian ini menggunakan NLTK (Natural Language ToolKit) sebagai library untuk pengolahan kata. Tahapan-tahapan preprocessing yang diterapkan pada penelitian ini yaitu sebagai berikut:

1) Case Folding: Proses pengubahan huruf besar menjadi huruf kecil.

Tabel 2. Contoh Case Folding

\begin{tabular}{|c|c|}
\hline Saran & Case Folding \\
\hline $\begin{array}{l}\text { Pelayanan Sangat baik dan } \\
\text { diberikan arahan dengan } \\
\text { baik dan ramah }(;) ;\end{array}$ & $\begin{array}{l}\text { pelayanan sangat baik dan } \\
\text { diberikan arahan dengan baik } \\
\text { dan ramah }(;) ;\end{array}$ \\
\hline
\end{tabular}

2) Stopword Removal: Proses mengeliminasi kata-kata yang dianggap tidak penting.

Tabel 3. Contoh Stopword Removal

\begin{tabular}{lllr}
\hline Saran & \multicolumn{3}{c}{ Stopword Removal } \\
\hline pelayanan sangat baik dan & pelayanan sangat baik \\
diberikan arahan dengan & diberikan arahan baik ramah \\
baik dan ramah $(-)(-)$ & $(-)$ & \\
\hline
\end{tabular}

3) Emoticon Removal: Proses mengeliminasi emoticon-emoticon yang terdapat dalam kalimat.

Tabel 4. Contoh Emoticon Removal

\begin{tabular}{llll}
\hline \multicolumn{2}{c}{ Saran } & \multicolumn{2}{c}{ Emoticon Removal } \\
\hline $\begin{array}{l}\text { pelayanan sangat baik dan } \\
\text { diberikan arahan dengan } \\
\text { baik dan ramah }(-) \cdot ;\end{array}$ & $\begin{array}{l}\text { pelayanan sangat baik } \\
\text { diberikan arahan baik ramah }\end{array}$ \\
\hline
\end{tabular}

4) Tokenization: Pemecahan kalimat menjadi kumpulan kata.

\begin{tabular}{cc}
\multicolumn{3}{c}{ Tabel 5. Contoh Tokenization } \\
\hline Saran & \multicolumn{1}{c}{ Tokenization } \\
\hline $\begin{array}{l}\text { pelayanan } \\
\text { diberikan arahan baik ramah }\end{array}$ & $\begin{array}{l}\text { ["pelayanan", "sangat", "baik", } \\
\text { "diberikan", "arahan", "baik", } \\
\text { "ramah"] }\end{array}$ \\
\hline
\end{tabular}

\subsection{Automatic Labelling}

Data labeling pada penelitian ini dilakukan secara otomatis, karena untuk melakukan manual labeling dibutuhkan waktu yang cukup lama. Automatic labeling telah banyak dilakukan, salah satunya melabeli kalimat sebagai positif, jika kalimat tersebut mengandung lebih banyak kata positif dan sebaliknya. Kata-kata negasi, seperti tidak dan bukan, juga akan mempengaruhi proses pelabelan (Wicaksono et al., 2014). Pada penelitian ini, pelabelan data dilakukan dengan cara yang hampir sama, yaitu memberikan skor sentimen berdasarkan kata-kata yang dikandung dalam data tersebut dengan menggunakan SentiStrength (Wahid \& SN, 2016). Berdasarkan skor yang didapat, data saran kemudian diberikan label positif yang ditandai dengan angka 1 (jika skor total kata dengan sentimen positif lebih besar dari skor total kata dengan sentiment negative dan netral), label negatif yang ditandai dengan angka 0 (jika skor total kata dengan sentiment positif lebih kecil dari skor total kata dengan sentiment negative dan netral) dan label netral yang ditandai dengan angka 2 (jika skor total kata dengan sentiment netral lebih besar dari skor total kata dengan sentiment negative dan positif).

Tabel 6. Data Saran dengan Label

\begin{tabular}{lcccc}
\hline \multirow{2}{*}{ Departemen } & Jumlah & \multicolumn{3}{c}{ Label } \\
\cline { 3 - 5 } & Saran & Positif & Negatif & Netral \\
\hline BAAK & 1200 & 600 & 300 & 300 \\
\hline BSTI & 1200 & 600 & 300 & 300 \\
\hline Kemahasiswaan & 1200 & 600 & 300 & 300 \\
\hline Kerja Sama & 1200 & 600 & 300 & 300 \\
\hline Keuangan & 1200 & 600 & 300 & 300 \\
\hline Perpustakaan & 1200 & 600 & 300 & 300 \\
\hline Sarana & 1200 & 600 & 300 & 300 \\
\hline TOTAL & $\mathbf{8 4 0 0}$ & $\mathbf{4 2 0 0}$ & $\mathbf{2 1 0 0}$ & $\mathbf{2 1 0 0}$ \\
\hline
\end{tabular}

\subsection{Training Word2Vec Model}

Training Word2vec model dilakukan untuk mendapatkan word embedding yang akan digunakan dalam proses klasifikasi sentiment nantinya. Training Word2vec model pada penelitian ini dilakukan dengan menggunakan kumpulan artikel Wikipedia berbahasa Indonesia (terdiri dari 415.521 kalimat dan 443.979 kata unik) dan tool yang digunakan yaitu gensim. Kemudian, word embedding yang sudah didapat di fine-tune dengan kata-kata yang ada pada data saran, agar word embedding yang terbentuk lebih sesuai konteks. Dimensi word embedding yang digunakan pada penelitian ini yaitu 50 dimensi. 


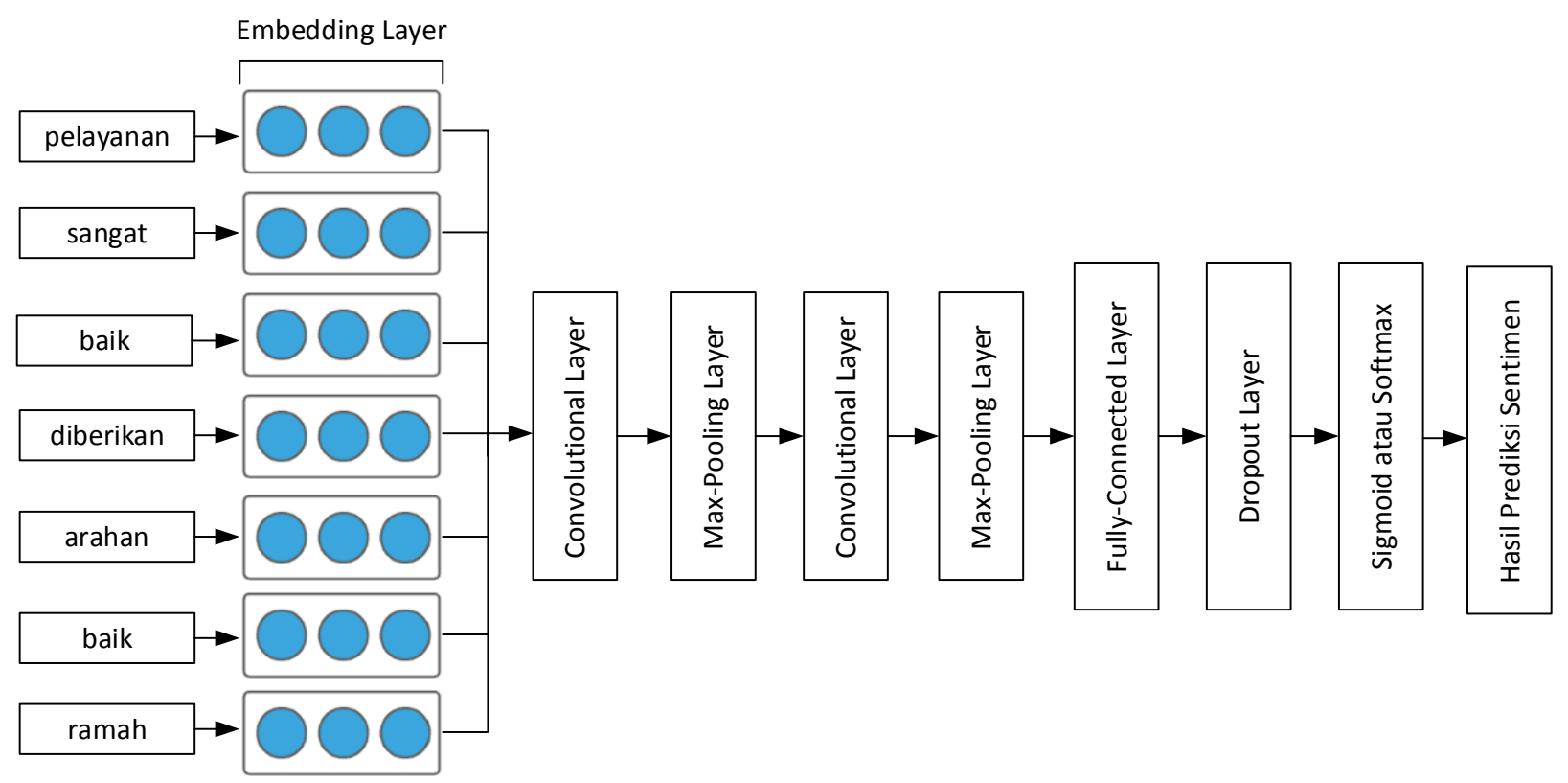

Gambar 3. Arsitektur Double-Max CNN

\subsection{Skema Training}

Untuk melakukan training model $C N N$, data pada Tabel 5 digabungkan dan diacak dan kemudian dibagi menjadi data training, data evaluation, dan data testing dengan ratio 8:1:1. Data dibagi menjadi data training, data evaluation, dan data testing untuk memastikan performa model pada data evaluation terlebih dahulu sebelum menerapkannya pada data testing. Jika performa model pada saat training dan evaluation tidak jauh berbeda, maka dapat dikatakan model telah bekerja dengan baik. Network pertama yang digunakan yaitu Convolutional neural network dengan 2 buah Convolutional Layer dan penerapan Maxpooling setelah Convolutional Layer kedua (Simple CNN). Untuk dapat memahami arsitektur Simple CNN, dapat dilihat pada Gambar 3, dengan keadaan Max-Pooling layer setelah Convolutional Layer pertama dihapuskan. Pada CNN dengan arsitektur ini, hidden size yang digunakan berukuran 50, activation function yang digunakan yaitu relu, jumlah filter yaitu 2, 3, dan 5, max-pooling dengan ukuran 2, dengan optimizer yang digunakan yaitu adam (learning rate $=0.001$ ). Simple $C N N$ juga menerapkan dropout senilai 0.5. Jumlah epoch yang digunakan adalah 10 dan batch size yaitu 100.

Network kedua yang digunakan yaitu Convolutional neural network dengan 2 buah Convolutional Layer dan penerapan Maxpooling setelah masing-masing Convolutional Layer (DoubleMax $C N N$ ), seperti yang dijelaskan pada Gambar 3. Pada $C N N$ dengan arsitektur ini, hidden size yang digunakan berukuran 50, activation function yang digunakan yaitu relu, dan jumlah filter yaitu 2, 3, dan 5, max-pooling dengan ukuran 2 , dengan optimizer yang digunakan yaitu adam (learning rate $=0.001$ ). DoubleMax $C N N$ juga menerapkan dropout senilai 0.2. Jumlah epoch yang digunakan adalah 10 dan batch size yaitu 100 .
Semua proses pada sub bab ini diimplementasikan dengan menggunakan library keras.

\subsection{Hasil Pengujian}

Pengujian dilakukan dengan menggunakan beberapa metrics dari confusion matrix, yaitu akurasi dan $f 1$-score.

Tabel 7. Hasil Pengujian $C N N$ dengan 2 Kelas Sentimen

\begin{tabular}{cccccc}
\hline Network & Filter & Recall & Precision & Akurasi & $\begin{array}{c}\text { F1- } \\
\text { Score }\end{array}$ \\
\hline \multirow{2}{*}{$\begin{array}{c}\text { Simple } \\
\text { CNN }\end{array}$} & 2 & $98 \%$ & $96 \%$ & $97 \%$ & $96 \%$ \\
\cline { 2 - 6 } & 3 & $98 \%$ & $96 \%$ & $97 \%$ & $97 \%$ \\
\hline \multirow{2}{*}{$\begin{array}{c}\mathbf{5} \\
\text { DoubleMax } \\
\text { CNN }\end{array}$} & 2 & $88 \%$ & $\mathbf{9 6 \%}$ & $\mathbf{9 7 \%}$ & $\mathbf{9 7 \%}$ \\
\cline { 2 - 6 } & 3 & $86 \%$ & $93 \%$ & $90 \%$ & $88 \%$ \\
\hline
\end{tabular}

Tabel 7 menjelaskan mengenai hasil pengujian yang didapat dari klasifikasi 2 kelas sentimen dengan menggunakan Simple CNN dan DoubleMax CNN dengan dengan filter yang digunakan yaitu 2, 3, dan 5 . Dari hasil pengujian di tabel 7 dapat diketahui bahwa hasil terbaik didapatkan dengan menggunakan filter sebesar 5, baik pada Simple CNN maupun DoubleMax $C N N$. Pada Simple $C N N$, hasil pengujian antara menggunakan filter dengan ukuran 2, 3, dan 5 tidak terlalu mencolok, dimana Recall, Precision, Akurasi dan F1-Score tampak stabil. Namun, pada DoubleMax $C N N$, ukuran filter menjadi sangat berpengaruh, dimana filter dengan ukuran 5 mendapatkan hasil terbaik dengan perbedaan hasil yang sangat jauh dibandingkan dengan penggunaan filter dengan ukuran 2 dan 3, yaitu mencapai Recall 98\%, Precision 97\%, Akurasi 98\% dan F1-Score $98 \%$.

Tabel 8 menjelaskan mengenai hasil pengujian yang didapat dari klasifikasi 3 kelas sentimen dengan menggunakan Simple CNN dan DoubleMax CNN dengan dengan filter yang digunakan yaitu 2, 3, dan 5. 
Tabel 8. Hasil Pengujian $C N N$ dengan 3 Kelas Sentimen

\begin{tabular}{cccccc}
\hline Network & Filter & Recall & Precision & Akurasi & $\begin{array}{c}\text { F1- } \\
\text { Score }\end{array}$ \\
\hline \multirow{2}{*}{$\begin{array}{c}\text { Simple } \\
\text { CNN }\end{array}$} & $\mathbf{2}$ & $\mathbf{9 0 \%}$ & $\mathbf{9 0 \%}$ & $\mathbf{9 1 \%}$ & $\mathbf{9 0 \%}$ \\
\cline { 2 - 6 } & 3 & $88 \%$ & $88 \%$ & $89 \%$ & $88 \%$ \\
\cline { 2 - 6 } DoubleMax & 5 & $88 \%$ & $89 \%$ & $90 \%$ & $89 \%$ \\
\cline { 2 - 6 } CNN & 2 & $80 \%$ & $79 \%$ & $78 \%$ & $78 \%$ \\
\cline { 2 - 6 } & $\mathbf{5}$ & $62 \%$ & $77 \%$ & $70 \%$ & $62 \%$ \\
\hline
\end{tabular}

Dari hasil pengujian di tabel 8 didapatkan tren yang sama dengan hasil pengujian pada Tabel 7, dimana DoubleMax CNN dengan filter 5 mendapatkan hasil pengujian terbaik. Namun berbeda dengan saat klasifikasi 2 kelas sentimen, dapat diketahui bahwa hasil klasifikasi 3 kelas sentimen terbaik dengan menggunakan Simple CNN didapatkan dengan menggunakan filter ukuran 2 yang mencapai Recall, Precision dan F1-Score 90\%, dengan akurasi $91 \%$. Walau hasil pengujian ketika menggunakan filter ukuran yang lebih besar yaitu 2 dan 3 tidak terlalu signifikan. Pada DoubleMax CNN, sama seperti saat mengklasifikasi 2 kelas sentimen, hasil terburuk didapatkan pada saat penggunaan filter ukuran 3 dengan Recall 62\%, Precision 77\%, F1-Score 62\% dan Akurasi $70 \%$. Penggunaan ukuran filter tampak sangat berpengaruh pada DoubleMax CNN yang ditunjukkan dengan perbedaan hasil pengujian Recall, Precision, F1-Score dan akurasi yang besar antara penggunaan filter ukuran 2, 3 dan 5 .

Tabel 9 menjelaskan perbandingan hasil klasifikasi sentimen dengan menggunakan Support Vector Machine (SVM), Logistic Regression, Nä̈ve Bayes dan CNN.

Tabel 9. Perbandingan Hasil Klasifikasi Sentimen berbagai Metode

\begin{tabular}{ccccc}
\hline \multirow{2}{*}{ Classifier } & \multicolumn{2}{c}{ 2 Kelas Sentimen } & 3 Kelas Sentimen \\
\cline { 2 - 5 } & Akurasi & $\begin{array}{c}\text { F1- } \\
\text { Score }\end{array}$ & Akurasi & $\begin{array}{c}\text { F1- } \\
\text { Score }\end{array}$ \\
\hline SVM & $94 \%$ & $93 \%$ & $85 \%$ & $84 \%$ \\
\hline Nä̈ve Bayes & $61 \%$ & $61 \%$ & $46 \%$ & $45 \%$ \\
\hline $\begin{array}{c}\text { Logistic } \\
\text { Regression }\end{array}$ & $93 \%$ & $92 \%$ & $85 \%$ & $84 \%$ \\
\hline Simple CNN & $\mathbf{9 7 \%}$ & $\mathbf{9 7 \%}$ & $\mathbf{9 1 \%}$ & $\mathbf{9 0 \%}$ \\
\hline DoubleMax CNN & $\mathbf{9 8 \%}$ & $\mathbf{9 8 \%}$ & $\mathbf{9 1 \%}$ & $\mathbf{9 0 \%}$ \\
\hline
\end{tabular}

Dari hasil perbandingan di tabel 9, dapat diketahui bahwa $C N N$, baik Simple $C N N$ maupun DoubleMax CNN memiliki performa terbaik, dari segi Akurasi, Recall, Precision dan F1-Score, pada saat klasifikasi 2 dan 3 kelas sentimen, jika dibandingkan dengan 3 metode lainnya, yaitu SVM, Nä̈ve Bayes, dan Logistic Regression dengan TF-IDF sebagai representasi teks. DoubleMax CNN berhasil mencapai Akurasi dan Fl-Score tertinggi sebesar $98 \%$ pada klasifikasi 2 kelas sentimen. Pada klasifikasi 3 kelas sentimen, DoubleMax CNN dan Simple CNN menunjukkan performa yang sama dengan Akurasi dan F1-Score terbaik mencapai $91 \%$ dan $90 \%$. Sementara itu, di antara metode non CNN, SVM memiliki hasil terbaik, yang disusul oleh Logistic Regression. Hasil terendah ditunjukkan oleh metode Nä̈ve Bayes mencapai akurasi terendah mencapai $46 \%$ pada klasifikasi 3 kelas sentimen.

Sementara itu, Gambar 4 dan 5 menjelaskan perkembangan akurasi yang didapat pada setiap epoch pada saat training dan evaluation Simple $C N N$ dan DoubleMax CNN.

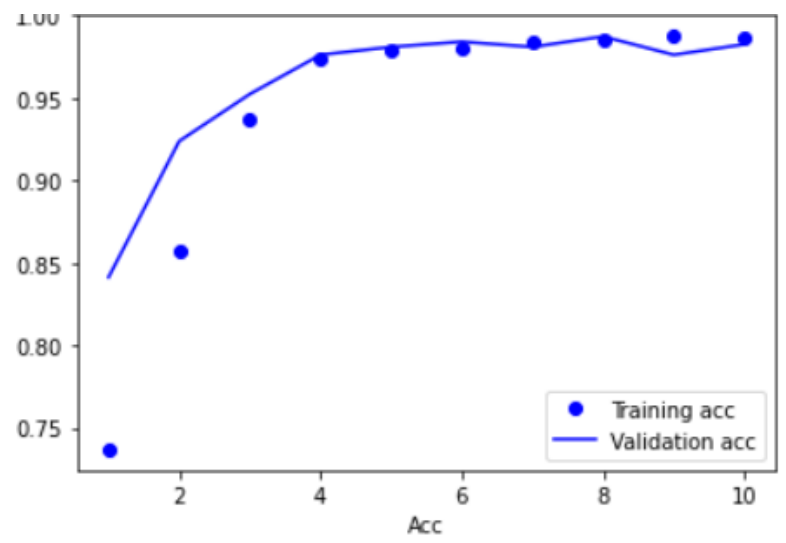

Gambar 4. Akurasi pada saat Training dan Evaluation di setiap Epoch dengan menggunakan Simple CNN

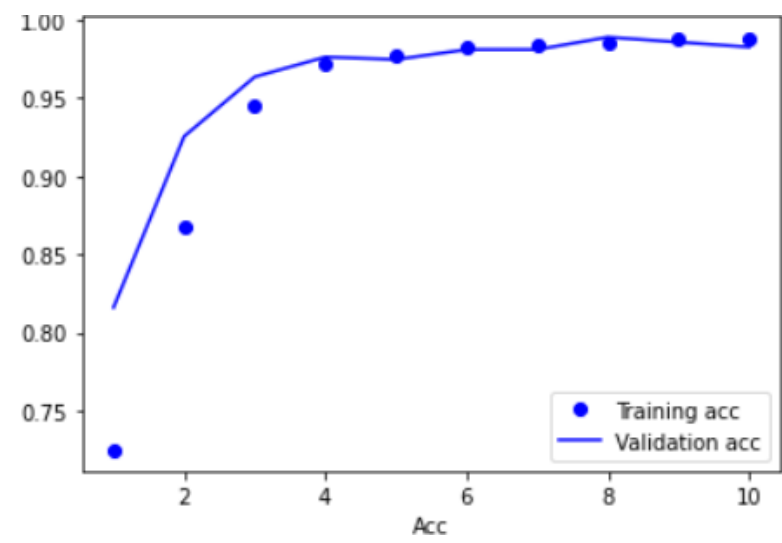

Gambar 5. Akurasi pada saat Training dan Evaluation di setiap Epoch dengan menggunakan DoubleMax CNN

Berdasarkan Gambar 4 dan 5 dapat disimpulkan bahwa CNN model yang digunakan bekerja dengan baik, karena tidak terdapat perbedaan yang besar antara akurasi pada data training dan data evalution di setiap epoch. Akurasi meningkat secara stabil mulai dari epoch 1 sampai dengan epoch 4. Namun, mulai dari epoch 5 sampai dengan 10, akurasi tidak mengalami peningkatan yang signifikan dan cenderung stagnan.

Berdasarkan beberapa pengujian yang telah dilakukan di atas, dapat disimpulkan bahwa $C N N$, baik Simple CNN maupun DoubleMax CNN dapat bekerja dengan sangat baik dalam melakukan analisis sentimen data saran mahasiswa terhadap kinerja departemen di perguruan tinggi. Walau data saran mahasiswa yang digunakan pada penelitian ini dapat berisi kalimat yang sangat panjang, yakni mencapai 150 kata, $C N N$ dapat menghasilkan representasi kalimat yang sangat baik, sehingga performa analisis sentimen juga menjadi lebih baik. Simple $C N N$ berhasil mencapai akurasi sebesar $97 \%$ dan 91\%, masing-masing untuk 2 dan 3 kelas sentimen. Sedangkan DoubleMax CNN mendapatkan 
akurasi yang lebih baik dibandingkan Simple CNN, yaitu akurasi klasifikasi sentimen yang mencapai $98 \%$ dan $91 \%$, masing-masing untuk 2 dan 3 kelas sentimen.

\section{KESIMPULAN}

Berdasarkan hasil pengujian yang telah dilakukan dapat disimpulkan bahwa DoubleMax CNN dengan filter ukuran 5 memiliki hasil terbaik pada klasifikasi 2 dan 3 kelas sentimen. Pada klasifikasi 2 kelas sentimen, DoubleMax CNN mendapatkan Akurasi dan F1-Score sebesar 98\%. Pada klasifikasi 3 kelas sentimen, DoubleMax CNN mendapatkan Akurasi dan F1-Score sebesar $91 \%$ dan $90 \%$. Dibandingkan dengan metode klasik machine learning seperti SVM, Logistic Regression dan Nä̈ve Bayes, DoubleMax CNN bekerja rata-rata $17 \%$ lebih baik dalam melakukan klasifikasi sentimen data saran. Hal ini menunjukkan bahwa $C N N$ dengan arsitektur yang lebih kompleks memiliki performa yang lebih baik dalam menganalisis sentimen data saran mahasiswa, bahkan untuk kalimat yang panjang. Kemudian, dapat pula disimpulkan bahwa pada saat menggunakan $C N N$ dengan penerapan Maxpooling di masing-masing layer, pemilihan filter yang tepat menjadi sangat penting. Penerapan filter pada teks sama seperti penerapan $\mathrm{N}$-Gram, sehingga pemilihan filter yang tepat akan menyebabkan representasi teks yang baik pula. Pada penelitian ini, penggunaan filter ukuran 5 pada arsitektur DoubleMax CNN merupakan ukuran filter yang paling tepat dibandingkan dengan filter ukuran 2 dan 3.

Pada penelitian mendatang, CNN dengan arsitektur yang mirip akan digunakan untuk melakukan multiclass classification pada data saran, yaitu mengklasifikasi data saran berdasarkan emosi yang tertuang pada pada saran menjadi bahagia/senang, marah, jijik, netral dan sedih. Untuk dapat melakukan penelitian mendatang, hal yang perlu dilakukan adalah mengumpulkan lebih banyak data saran dari tahun akademik terbaru dan melakukan manual labelling karena belum terdapat metode untuk melakukan automatic labelling untuk memberikan label emosi pada teks.

\section{DAFTAR PUSTAKA}

AL KABIR, A.H., BASUKI, S. \& WICAKSONO, G.W., 2019. Analisis sentimen kritik dan saran pelatihan aplikasi teknologi informasi (PATI) menggunakan algoritma support vector machine (SVM). Jurnal Repositor, 1(1), hal.39.

ATTABI, A.W., MUFLIKHAH, L. \& FAUZI, M.A., 2018. Penerapan Analisis Sentimen untuk Menilai Suatu Produk pada Twitter Berbahasa Indonesia dengan Metode Naïve Bayes Classifier dan Information Gain. Jurnal Pengembangan Teknologi Informasi dan Ilmu Komputer, 2(11), hal.4548-4554.

DOZAT, T., 2016. Incorporating Nesterov Momentum into Adam. ICLR Workshop, (1), hal.2013-
2016.

GUPTA, P., TIWARI, R. \& ROBERT, N., 2016. Sentiment analysis and text summarization of online reviews: A survey. In: International Conference on Communication and Signal Processing, ICCSP 2016, hal.241-245.

HAMZAH, A., 2014. Sentiment Analysis Untuk Memanfaatkan Saran Kuesioner Dalam Evaluasi Pembelajaran Dengan Menggunakan Naive Bayes Classifier (NBC). In: Prosiding Seminar Nasional Aplikasi Sains \& Teknologi (SNAST), hal.159.

JUWIANTHO, H., SETIAWAN, E.I., SANTOSO, J. \& PURNOMO, M.H., 2020. Sentiment Analysis Twitter Bahasa Indonesia Berbasis Word2Vec Menggunakan Deep Convolutional Neural Network. Jurnal Teknologi Informasi dan Ilmu Komputer (JTIIK), 7(1), hal.181-188.

KIM, H. \& JEONG, Y.S., 2019. Sentiment classification using Convolutional Neural Networks. Applied Sciences (Switzerland), 9(11), hal.1-14.

KIM, Y., 2014. Convolutional neural networks for sentence classification. In: EMNLP 2014 . 2014 Conference on Empirical Methods in Natural Language Processing, Proceedings of the Conference. hal.1746-1751.

KINGMA, D.P. \& BA, J.L., 2015. Adam: A method for stochastic optimization. In: 3rd International Conference on Learning Representations, ICLR 2015 - Conference Track Proceedings, hal.1-15.

LIU, B., 2010. Sentiment Analysis and Subjectivity. In: N. Indurkhya \& F. J. Damerau (ed.), Handbook of Natural Language Processing, Chapman \& Hall/CRC, hal.272277.

MIKOLOV, T., CHEN, K., CORRADO, G. \& DEAN, J., 2013. Efficient estimation of word representations in vector space. In: $1 s t$ International Conference on Learning Representations, ICLR 2013 - Workshop Track Proceedings, hal.1-12.

PANG, B. \& LEE, L., 2008. Opinion Mining and Sentiment Analysis. Foundations and Trends in Information Retrieval, 2(1-2), hal.1-135.

RAUT, V.B. \& LONDHE, D.D., 2014. Opinion mining and summarization of hotel reviews. In: 6th International Conference on Computational Intelligence and Communication Networks, CICN 2014, hal.556-559.

RUDER, S., 2016. An overview of gradient descent optimization algorithms. arXiv preprint arXiv:1609.04747. [online] Tersedia di: <https://arxiv.org/abs/1609.04747>

SALAM, N.S.N., SUPIANTO, A.A. \& PERDANAKUSUMA, A.R., 2019. Analisis 
Sentimen Opini Mahasiswa Terhadap Saran Kuesioner Penilaian Kinerja Dosen dengan Menggunakan TF-IDF dan K-Nearest Neighbor. Jurnal Pengembangan Teknologi Informasi dan Ilmu Komputer, [online] 3(6), hal.6148-6156. Tersedia di: <http://jptiik.ub.ac.id/index.php/jptiik/article/view/5649>.

SEYEDITABARI, A., TABARI, N. \& ZADROZNY, W., 2018. Emotion Detection in Text: a Review. arXiv preprint arXiv: 1806.00674. [online] Tersedia di: <https://arxiv.org/abs/1806.00674>

TSYTSARAU, M. \& PALPANAS, T., 2012. Survey on mining subjective data on the web. Data Mining and Knowledge Discovery, 24(3), hal.478-514.

WAHID, D.H. \& SN, A., 2016. Peringkasan Sentimen Esktraktif di Twitter Menggunakan Hybrid TFIDF dan Cosine Similarity. IJCCS (Indonesian Journal of Computing and Cybernetics Systems), 10(2), hal.207.

WICAKSONO, A.F., VANIA, C., DISTIAWAN, B.T. \& ADRIANI, M., 2014. Automatically building a corpus for sentiment analysis on Indonesian tweets. In: Proceedings of the 28th Pacific Asia Conference on Language, Information and Computation, PACLIC 2014. hal.185-194.

ZEILER, M.D., 2014. Adadelta: An Adaptive Learning Rate Method. arXiv preprint arXiv: 1212.5701. [online] Tersedia di: $<$ https://arxiv.org/abs/1212.5701> 